\title{
Impact of prenatal technologies on the sex ratio in India: an overview
}

\author{
Kamlesh Madan, $\mathrm{PhD}^{1}$ and Martijn H. Breuning, $\mathrm{MD}, \mathrm{PhD}^{1}$
}

\begin{abstract}
The fact that techniques of prenatal diagnosis are used in India and China to selectively eliminate females is widely known. It has been extensively reported in the international media and in scientific publications since the 1990s. The publication of the Census of India 2011 shows that the ratio of girls to boys below the age of 6 years continues to decline at an alarming rate. Following that publication, this topic has again received international attention. The aim of this article is to better inform the human genetics community of the magnitude of this practice and its consequences in India.
\end{abstract}

The development of increasingly easier methods of prenatal sex detection is a blessing for families with sex-linked genetic diseases. However, in South and East Asia, these methods have been and are being used to determine the sex of the fetus before selectively aborting females.

Although many people are aware that prenatal diagnosis (PD) is misused for this purpose in India and China, very few know the extent of this practice and its consequences. The purpose of this brief overview is to make the human genetics community aware of the magnitude of the misuse of prenatal technologies and its impact on the sex ratio in India and to stimulate discussion and exploration of possible solutions.

We would like to state at the outset that PD is legitimately used in India for detecting genetic defects, and there is a wide range of genetic diseases that are being diagnosed prenatally. ${ }^{1}$ However, in this article, we shall concentrate on the misuse of prenatal technology, which has contributed to the skewed sex ratio in India.

Skewed sex ratio in favor of males has been a matter of concern since the first census held in India in $1871 .^{2}$ The sex ratio at birth in most countries shows that there are slightly more boys than girls, 1,000 boys to 952 girls; among adults, it is expected to be close to 1:1. The data from the Census of India, which is held every 10 years, are not on newborn children but on older persons. Unless otherwise indicated, we have used the definition of sex ratio as expressed in the Census of India, namely, the number of females per 1,000 males. The subject of declining sex ratio in India was extensively reported in the media in the 1990s following the census of 1991. In the 10 years following the census of 2001, the topic again received attention in the media, in international scientific journals, and in books. ${ }^{3-10}$ The
In this overview, we examine the impact of prenatal technology on the sex ratio in India. We present facts and figures from the Census of India and other publications that show that the practice is wide spread throughout India, in urban and rural areas, among the rich and the poor, and among the educated and the illiterate. We also briefly discuss the possible causes, consequences, and solutions.

Genet Med advance online publication 31 October 2013

Key Words: prenatal technology; sex ratio in India

Census of India 2011 has shown that the sex ratio in India in the age group of 0-6 years continues to deteriorate at an alarming rate. ${ }^{11}$ The problem is now widely reported in the media and on the internet. Documentaries on the Indian TV, in the United States and worldwide, and campaigns to save the girl child have drawn attention to this issue. Estimates of the number of missing girls worldwide vary from 100 to 200 million..$^{12,13}$

\section{FEMALE INFANTICIDE AND EXCESS OF INFANT MORTALITY AMONG GIRLS}

The overall sex ratio in India went down from 972 in 1901 to 930 in 1971 (ref. 11). This decline in the number of girls until the 1970s was attributed mainly to two causes: excess child mortality of girls and female infanticide, both of which apply mostly to girls born to mothers with at least one surviving daughter. ${ }^{14,15}$ Mortality among girls is 1.5-2 times higher than that for boys below the age of 4 years and 1.3 times higher than that for boys below the age of 1 year. ${ }^{14,16}$ This is ascribed to neglect, malnutrition, and deprivation of medical care. ${ }^{14,16-18}$ Female infanticide has been a growing problem in India. There are records dating back to 1789 of female infanticide in the northwest of British India: Rajasthan, Gujarat, Surat, and Kutch. In 1795, infanticide was made punishable in the North-West provinces and a law against infanticide, the Infanticide Regulation Act, was passed in $1870 .{ }^{17,19,20}$ Since the independence of India in 1947, female infanticide has also been reported in a southern state, Tamil Nadu. ${ }^{7,15}$ Certain communities and castes are more prone to female infanticide, but the custom has spread out from the core areas. ${ }^{19}$ It has now been reported in most states right up to Bihar and Orissa in the east and Kerala in the south., ${ }^{9,1920}$ The various methods used for female infanticide, which are region 
specific, often ritualized, and enjoy social acceptance, are well documented. ${ }^{3,9,15,20-22}$ Until the advent of PD, female infanticide was the most widely used method for the elimination of girls in rural areas.

\section{IMPACT OF PD}

Although the overall sex ratio in 1971 was 930 , it was $<900$ in many of the north-western states and close to or $>1,000$ in the south-eastern states. This rough north-south line divides India also by culture and language. In the north, Indo-European languages are spoken, and the society is patriarchal, whereas Dravidian languages are spoken in the south, and the society is more matriarchal. Nevertheless, as mentioned above, female infanticide had spread across this north-south line.

The advent of PD in the 1970s brought a major change. Since then, the combination of prenatal sex determination and selective abortion has been widely used for the systematic elimination of females.

PD became available soon after abortion was legalized in 1971. PD was introduced in India as a method for detecting fetal abnormalities but was soon used for prenatal sex selection. ${ }^{3,7}$ The Indian medical profession actively promoted it for this purpose. ${ }^{6,8,9,23}$ Prenatal sex selection was seen as a solution to a number of problems: it would fulfill the desire of families for a son, result in happier marriages, and make the life of women easier; it would stop female infanticide; it would stop women repeatedly reproducing till they had a son and was seen as an important part of India's population control program. ${ }^{6,8,9,23}$

First amniocentesis in the 1970s and later chorionic villus sampling in the 1980s were openly advertised and extensively used in urban areas for sex-selective abortions. ${ }^{24}$ The effect became soon apparent. One of the earliest studies on the result of amniocentesis was carried out over a 12-month period, 1976-1977, in an urban hospital; $96 \%$ of the girls (430/450) were aborted, whereas all 250 boys, even with the risk of a genetic defect, were born. ${ }^{17}$ Results from an abortion center in Mumbai showed that almost 100\% of the 15,914 abortions carried out following sex determination during 1984-1985 were of females. Another study of 6 city hospitals in Mumbai reported in 1988 found that 7,999 of the 8,000 aborted fetuses were girls. ${ }^{7}$ Amniocentesis and chorionic villus sampling require qualified medical and laboratory staff and expensive equipment and were, therefore, available mostly to the affluent and the wellinformed part of the population in the cities.

In the early 1980s, the ultrasound method, which is noninvasive and cheap, was introduced. Within a few years, tens of thousands of ultrasound scanners were produced by manufacturers of medical equipment and sold throughout India, with a disproportionate number in north west India, to medical professionals and possibly also to quacks. ${ }^{5,25}$ Equipped with such a portable machine and a minimum means of transport, medical professionals were able to reach even the remotest villages in India, villages with no electricity or running water. ${ }^{8}$ Ultrasound was advertised on thousands of billboards throughout India with "pay five hundred rupees now [US\$14] rather than five lakhs [Rs 500,000 or US\$14,000] later."3 This was to encourage people to abort female fetuses and save on a future dowry (see dowry as one of the causes below). ${ }^{3,8,21}$ Some Indian women believe that the main purpose for developing ultrasound machines was for fetal sex selection. ${ }^{26}$ With the extensive use of ultrasound, selective female feticide spread through the socioeconomic layers, from the cities to the rural areas, as well as geographically throughout India, from the north-west to the east and even to the south., ${ }^{2,5}$

Two preconception methods became available in the $1980 \mathrm{~s}$ and 1990s. Various X and Y sperm separation methods, ${ }^{3}$ particularly the microsort method, ${ }^{27}$ which increase the chance of a male child, have been used by couples who prefer preselection of sperm to sex-selective abortion., ${ }^{3,9}$ The microsort method gives $90 \%$ purity of $\mathrm{X}$ or $\mathrm{Y}$ sperm. ${ }^{28}$ When preimplantation genetic diagnosis, which is highly invasive and expensive, became available, it was advertised and offered as a more ethical method than selective abortion till mid-2003 when it was forbidden by the Indian Supreme Court. ${ }^{3,6,29,30}$ Neither of these two methods has contributed much to the decline in sex ratio, but we mention them to show that every available method to prevent the birth of a girl has been used.

Detection of a male fetus from cell-free fetal DNA in maternal blood became possible in the mid-2000s. Companies in the United States have been providing DNA kits for home use, which have been freely available and widely used in the north-western states of Punjab and Haryana since $2006 .{ }^{9}$ Blood from a finger prick from the pregnant woman in the seventh week of pregnancy could be sent to a laboratory in the United States by post, and the result was known in 10 days. In recent years, various approaches for noninvasive prenatal testing, which give results early in pregnancy, have been developed. The use of these techniques for detecting common aneuploidies has been reviewed. ${ }^{31}$ The use of noninvasive prenatal testing for genetic diagnosis in India would fall under the PCPNDT Act (see below). In the context of sex selection, illegal use of noninvasive prenatal testing would have to compete with the easily available ultrasound technology. However, one can expect the development of illegal home-use kits in the future.

In 1975, medical researchers had claimed that selective abortion of female fetuses would not affect the sex ratio. ${ }^{6}$ However, the results of the 1981 census already showed skewing of the sex ratio among children, and there were concerns about the sex imbalance in the population. ${ }^{23}$ Concerns were further raised following the census of $1991,,^{3-5}$ and a law banning the use of prenatal technologies for sex selection, the Pre-Natal Diagnostic Techniques (PNDT) Act, was passed in 1994, which came into effect in 1996. According to this law, genetic laboratories may not directly or indirectly reveal the sex of the fetus, except in cases of sex-linked diseases. The law was further amended in 2003 to include preconception sex-selection techniques, regulation of sale of ultrasound machines, and more stringent punishments for breaking the law. It was now called the Preconception Pre-Natal Diagnostic Techniques Act (PCPNDT 
Act) ${ }^{8,9}$ Nevertheless, elimination of females using these methods has continued unabated during the past 40 years. Although selective feticide concerns only $2-4 \%$ of pregnancies carrying a girl, the numbers are very large in absolute terms. ${ }^{32}$ Estimates of the number of girls missing as a result of selective feticide range from a quarter to half a million per year., ${ }^{8,25,32-34}$ Female feticide was considered as a more acceptable alternative to female infanticide, but it did not always replace female infanticide. Those who would not have contemplated infanticide are making massive use of selective female feticide, whereas female infanticide is still practiced in rural areas by families who either have no access to or cannot afford the prenatal tests. ${ }^{15,19}$ It also appears that female infanticide is making a comeback since the legal restriction on prenatal sex selection. ${ }^{9}$ It is difficult to find information on the number of female infanticides per year as the communities and villages where it occurs are very secretive about it. ${ }^{15,19}$ However, the following estimates should give some idea of the extent of the problem. In one district in Bihar, there were 1,000 female infanticides per year. ${ }^{19}$ In 1995, midwives interviewed in Bihar confessed to killing $50 \%$ of the girls they delivered..$^{10}$ In 2005, it was reported that in Kerala alone, $\sim 25,000$ female infanticides occurred in a year. ${ }^{9}$ Altogether, these estimates are impressive.

The overall sex ratio of 940 in 2011 (Table 1) is slightly up from 933 in $2001 ;{ }^{11}$ the increase has been attributed to the inclusion of older women who are now living longer due to better health care. $^{20}$ The sex ratio of 914 among children between 0 and 6 years, however, is disturbingly low (Table 1); it is the lowest since records for this age group have been kept (Figure 1). In some individual states, it is well below 900 (Table 2).

This sharp decline in the child sex ratio since the 1970s is now unequivocally linked to the widespread use of prenatal sex determination and selective abortions of girls. ${ }^{4-9,32}$ States with a higher number of registered prenatal diagnostic facilities per 100,000 women have a lower child sex ratio than states where these facilities are less available. ${ }^{2,35}$

\section{WHAT ARE THE REASONS FOR THE PREFERENCE FOR A BOY?}

For an answer to this question, the reader is referred to the large number of publications on the subject. ${ }^{7-10,17}$ In her book, Banerji $1^{10}$ takes one through the cultural, religious, and political changes in the past 3,000 years that have shaped the attitude toward women in India. Aravamudan ${ }^{9}$ describes the results of her 10-year field study in India. In this article, we summarize the most important reasons that have been given. Indian society, particularly in the north and west, is very patriarchal with a deep-rooted preference for boys. In India, as in China and

Table 1 Data from the Census of India 2011 showing the number of males and females in the population ${ }^{11}$

\begin{tabular}{lcccc} 
& Total & Males & Females & Sex ratio \\
\hline All persons & $1,210,193,422$ & $623,724,248$ & $586,469,174$ & 940 \\
0-6 year olds & $158,789,287$ & $82,952,135$ & $75,837,152$ & 914 \\
\hline
\end{tabular}

many societies, the male is considered the breadwinner and the carrier of the family name and the business. ${ }^{36}$ In China and India, a son also provides security in old age. The girl, on the other hand, is considered a future member of another house hold, namely, that of her husband., ${ }^{9,14,17,20,21}$ One of the sayings in India is "raising a girl is like watering a plant in your neighbor's yard" (ref. 10). One cultural reason for boy preference in India is that a son, but not a daughter, may light the funeral pyre of the parents to secure salvation after death. ${ }^{7,21,22,37}$ The preference for a boy is so deep rooted that also women prefer to have sons. Giving birth to a son gives them social status and acceptance within the husband's family. ${ }^{14,17,20,26,37}$ Pregnant women are often pressured by their husbands and members of his family, sometimes including verbal and physical abuse, to undergo prenatal sex determination and to abort the fetus if it is a female. ${ }^{7,822,26}$ It should be noted that, as for victims of female infanticide or neglect, selective abortion of girls is most likely in pregnancies after the firstborn is a girl. ${ }^{32,33,38}$ Social demand for smaller families may further increase the sex bias. ${ }^{39}$

Whereas in China the one child policy since 1979 is associated with the severe decline in the sex ratio, in India, the dowry system is the major cause. $3,7,8,17,19,20,26,36,40$ Dowry is an ancient custom of giving some personal wealth to a daughter, mostly in the form of jewelry, as she would not get any inheritance, which is for sons only. However, dowry has slowly changed its character over the past 150 years. It is now demanded by the family of the groom in the form of property and goods, and the demands have become exorbitant. ${ }^{8,9,19,37}$ The average price of the dowry can be equivalent to $\sim 6$ years of income of the bride's family. ${ }^{41}$

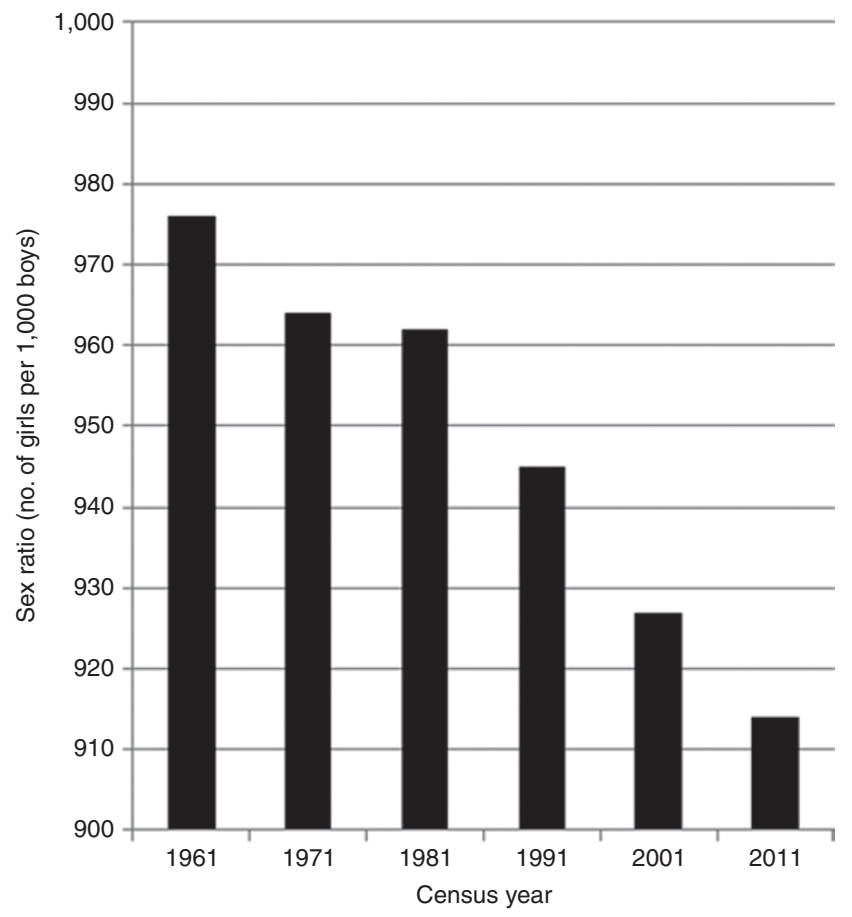

Figure 1 Data from Census of India 2011 showing the number of girls per 1,000 boys in the age group of 0-6 years in the period 19612011. ${ }^{11}$ 
This is financially crippling for the bride's family and is considered to be one of the biggest causes of the increase in female feticide and infanticide. Demands for more dowry payments continue for years after marriage. When these demands are not met, the husband and in-laws apply mental and physical pressure on the young bride to encourage her family to pay up. Such dowry disputes sometimes lead to what has become known as "dowry deaths" or "bride burning." The most common means of murder is setting the bride aflame after soaking her in kerosene. ${ }^{37,42,43}$ According to the National Bureau of Crime (2011), the rate of reported dowry deaths in the period 2007-2011 is $\sim 8,300$ per year. ${ }^{44}$ These are only the cases that were reported, which form a fraction of the real figure. Other estimates range from 15,000 to 25,000 per year. ${ }^{10}$ One might expect that the shortage of brides would lead to abolition of the dowry system. On the contrary, the price of dowry goes on increasing, particularly among the rich and the educated, in spite of the law passed against dowry in 1961 . The economics of dowry is very complicated, and the reader is referred to publications on the causes of the ever-increasing dowry price. ${ }^{37,45,46}$

\section{CONSEQUENCES OF THE DISTORTED SEX RATIO}

The most significant consequence is that there is a shortage of at least 37.3 million females in India. The difference between the number of males and females for all persons in Table 1 does not take into account that older women live longer. Furthermore, a sex ratio of 914 among children in the age group of 0-6 years means that $>7$ million young men in India will not have a partner in 10-15 years' time (Table 1). The child sex ratio in 2011 in the 35 individual states and union territories (which fall directly under the central government) ranges from 830 to 971 . In 8 states, there is a slight improvement in this sex ratio with respect to the figures in 2001 (although in 5 of these, it is still below the national average), but in 27 states, the child sex ratio has declined, also in traditionally "female-friendly" states in the south, Kerala, and Puducherry. ${ }^{11}$ Table 2 shows sex ratios for all

Table 2 Data from the Census of India 2011 showing the sex ratio in eight states/union territories of India, in 2001 and $2011^{11}$

\begin{tabular}{|c|c|c|c|c|}
\hline \multirow[b]{2}{*}{ India/state/union territory ${ }^{a}$} & \multicolumn{2}{|c|}{ Sex ratio } & \multicolumn{2}{|c|}{$\begin{array}{l}\text { Sex ratio } \\
\text { (0-6 years) }\end{array}$} \\
\hline & 2001 & 2011 & 2001 & 2011 \\
\hline India & 933 & 940 & 927 & 914 \\
\hline Chandigarh ${ }^{\mathrm{a}}$ & 777 & 818 & 845 & 867 \\
\hline Haryana & 861 & 877 & 819 & 830 \\
\hline Delhia & 821 & 866 & 868 & 866 \\
\hline Maharashtra & 922 & 925 & 913 & 883 \\
\hline Bihar & 919 & 916 & 942 & 933 \\
\hline Tamil Nadu & 987 & 995 & 942 & 946 \\
\hline Puducherrya & 1,001 & 1,038 & 967 & 965 \\
\hline Kerala & 1,058 & 1,084 & 960 & 959 \\
\hline
\end{tabular}

anion territories fall directly under the central government. persons and for children 0-6 years of age in 2001 and 2011 in eight selected states and union territories from different parts of India: Chandigarh, Haryana, and Delhi in the north-west; Maharashtra in the mid-west; Bihar in the east; and Tamil Nadu, Puducherry, and Kerala in the south. The shortage of women is more acute in Punjab, Haryana, and Rajasthan than that in other states. There are reports of some villages in Rajasthan with no female births in decades (ref. 9, p 46).

The consequences of millions of men not being able to find a mate are given below. It has been predicted that a shortage of women can lead to increase in violent crimes against women. ${ }^{4,8,21}$ There is evidence of increase in such crimes in China. ${ }^{36,40}$ Also in India, violent crimes against women have been linked to regions with adverse sex ratio. ${ }^{7}$ The rates of reported rapes, kidnappings, and abductions have increased drastically in India between 2006 and 2011 (Figure 2); ${ }^{44,47}$ these crimes have gone up much more sharply than other crimes. ${ }^{44}$

We have compared the map of India on page 82 of the 2011 report of the National Bureau of Crimes, showing the rate of crime against women in the various states, with map 11 in the Census of India showing the sex ratios in 2011.11,44 We note that states with some of the highest rates of crime against women, Haryana (21.7), Delhi (31.2), and Rajasthan (29.0), are the ones that have consistently had low sex ratios over the years, whereas one of the states with a low rate of crime against women, Tamil Nadu (9.6), is the state with one of highest sex ratios; the rates of crime are given per 100,000 population (males and females). The high rate of crime against women in the south (33.8 in Kerala) and in the eastern states (e.g., 33.4 in Andhra Pradesh, 31.9 in West Bengal, 22.5 in Orissa, and

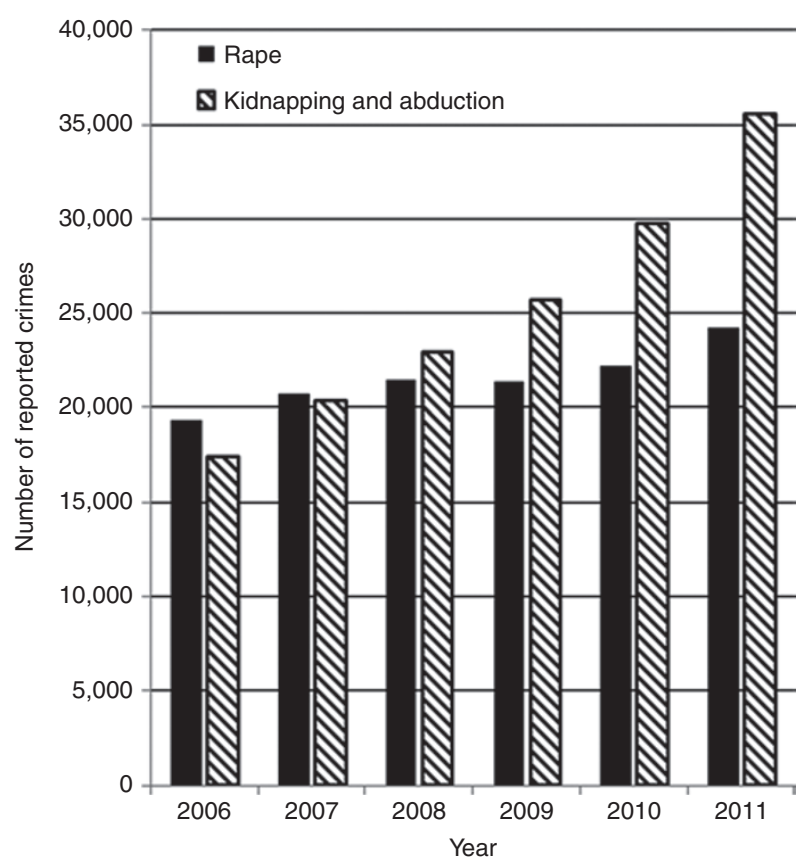

Figure 2 Number of rapes and kidnappings and abductions in India in the period 2006-2011. Data from the National Bureau of Crimes 2010 and $2011.42,45$ 
36.9 in Assam) does not directly correspond to the relatively high sex ratios in these states. It is beyond the scope of this article to analyze the crime data. However, large-scale trafficking of girls from the above-mentioned eastern states across state boundaries to the north-western states, where there is a shortage of girls, is widely reported, also in the newspapers and other media. ${ }^{9,48,49}$ This could explain, at least in part, the high crime rates in the eastern states. Girls kidnapped or bought from the parents in the poorer states in the east are sold to rich farmers in Punjab and Haryana in the west. One girl may be bought for all the males in a family (forced polyandry) and is expected to produce sons for the continuation of the male family line. ${ }^{7,9}$

Repeated abortions can have an adverse effect on the mental and physical health of women, especially on child brides. ${ }^{8,20}$ As the number of marriageable women declines, men tend to marry younger girls. ${ }^{8}$ According to figures released by United Nations Children's Fund (UNICEF), India already has one of the highest rates of child marriages in the world; $47 \%$ are married before the age of 18 years, and $18 \%$ are married before they reach 15 years. ${ }^{50}$ Girls younger than 15 years of age are five times more likely to die in child birth than women older than 20 years of age. Pregnancy is the leading cause of death of girls between the age of 15 and 19 years. ${ }^{51}$

Furthermore, discrimination against girls and murder of women at all stages of life devaluates women. An excess of males can lead to an aggressive and a generally unhappy society and may even pose a threat to global security. ${ }^{36,40,52}$

\section{WHAT IS BEING DONE, WHAT IS NOT WORKING, AND WHAT MIGHT GIVE RESULTS?}

\section{The necessary laws are in place}

The central government and various state governments have passed laws that should contribute to preventing the decline of the sex ratio (Table 3). Although the laws are in place, some for more than 50 years, they have not been sufficiently implemented. The Dowry Prohibition Act has been ineffective or difficult to enforce. Violations of this law, which involve prison sentences for both the receiver and the giver of a dowry, are seldom reported. Dowry is often claimed to be a voluntary gift. The bride's families often believe that the dowry may be the way to obtain a suitable match, to overcome the bride's shortcomings, or to secure favorable treatment in the home of the in-laws. ${ }^{37}$

Violation of the law against prenatal sex determination can result in fines of 10,000-50,000 rupees and prison sentences

\section{Table 3 Existing laws}

\begin{tabular}{lc} 
Laws & Year \\
\hline The Infanticide Regulation Act & 1870 \\
\hline The Child Marriage Restraint Act & 1929, amended 2006 \\
\hline The Dowry Prohibition Act & 1961, amended 1985 \\
\hline $\begin{array}{l}\text { The Pre-Natal Diagnostic Techniques (PNDT) Act } \\
\text { and the Pre-Conception Pre-Natal Diagnostic }\end{array}$ & 1994, amended 2003 \\
Techniques (PCPNDT) Act &
\end{tabular}

of 3-5 years. ${ }^{8}$ One of the difficulties in enforcing this law is that whereas prenatal sex determination is illegal, abortion is legal. It is very difficult to prove the connection between the two operations as they are often carried out by different professionals at different locations. ${ }^{4}$ The possible reasons for lack of implementation of the law, the role of the law enforcement authorities, and the medical profession as well as various ethical aspects have been discussed by several authors. ${ }^{4,6-9,15,35}$ The role of the medical profession in promoting the sex-selection technology, in violating the laws against sex selection, and concealing the crime has been emphasized in these articles. There is a demand for sex-selective abortions, and the business is very lucrative for the medical profession. ${ }^{3,4,6}$ Even when the doctors are prosecuted, few are convicted. The laws need to be implemented and the doctors held accountable. , $, 4,6,7,35,53^{-1}$

An important aspect is that the preference for a boy is deep rooted in the culture. It is difficult to implement these laws when medical professionals and the legal authorities all come from the same culture. ${ }^{8}$ Moreover, practices that are socially sanctioned but are considered offences in the eyes of the law are not likely to be reported. Banning these practices just moves them underground, leaving room for exploitation and corruption. ${ }^{3,4,54}$ Nevertheless, it is important that the laws of the country are implemented.

\section{Local support and health monitoring programs at community level}

India has many programs, run by governmental and nongovernmental organizations, at state level to provide information, support, and health monitoring for women. There are also educational sessions on reproductive matters at the community level. Many of these have been described by Aravamudan. ${ }^{9}$ There is also a large amount of information about these programs available on the Internet. Success of some of these became apparent in the slight improvement of child sex ratio in 2011 as compared with that in 2001 in, e.g., Haryana and Chandigarh (Table 2). Some of the programs are excellent and are useful for bringing about a change in culture but cannot bring about substantial changes in the sex ratio anytime soon.

\section{Financial incentives}

In the past decade, the Central and State Governments have launched schemes that give financial incentives to prevent female feticide and child marriages and to promote medical care and education of girls. ${ }^{55}$ George ${ }^{15}$ has discussed the limitations of some interventions by nongovernmental organizations to prevent infanticide and promote education of women in Tamil Nadu. He pointed out that financial incentives that become available around the time of marriage would be used for dowry and would help to legitimize this illegal practice. On the whole, some of the financial incentives offered to the poorer in society can help to improve the life of girls. However, they are unlikely to stop sex-selective abortions, which are more prevalent among the rich and the growing middle class (see below). 


\section{Education and training of women}

In the cities, women are relatively well represented in university education and in many professions, particularly medicine and education. ${ }^{56}$ Judging by the information from the media, there are many governmental and nongovernmental programs in rural India to train women in skills that make them financially self-sufficient. One can be cautiously optimistic with the figures on literacy rate in the Census of India ${ }^{11}$. The literacy rate for the whole of India has risen from $18.3 \%$ in 1951 to $74 \%$ in 2011 , with literacy among females being 64.5\%. However, there is a long way to go between being able to read and write and changing one's way of thinking. The existing programs are good for giving women self-confidence and a feeling of self-worth but do not address the issue of the sex ratio.

\section{Economic growth and education of women do not have a positive effect on the sex ratio}

It is often said that economic growth and education of women will improve the situation. However, most authors report that discrimination against girls, selective female feticide, and low sex ratio are more common among the educated and the prosperous part of the society throughout India., 2,3,6,714,21,32,35 The fact that excessive dowry demands are particularly prevalent among the rich and the educated has been amply reported in the media. ${ }^{9}$ Education and economic growth have not solved the problem of the declining sex ratio. This is supported by the following: (i) according to the Census of India, the sex ratios are consistently lower in urban than in rural areas since 1901 (ref. 57); (ii) the states that show low sex ratios and have had a low sex ratio consistently over the past decades are the richest and belong to the top 10 states with the highest per capita income or have the highest rate of education, i.e., Punjab, Haryana, Maharashtra, and Gujarat; ${ }^{11,32}$ (iii) a study published in the Lancet shows that the sex ratios are lower among educated mothers and in the $20 \%$ of the richest households than among uneducated mothers and $20 \%$ of the poorest households. ${ }^{32}$ Similar results were obtained by Varghese et al.; ${ }^{38}$ and (iv) there is increasing evidence from the United Kingdom, United States, and Canada that the sex ratios, among higher order children, are skewed among the Indian communities in Diaspora., ${ }^{9,268-61}$ In general, these communities do not suffer from poverty or lack of education.

\section{Worldwide attention}

There are many Indian medical doctors, scientists, and activists involved with this issue as is evident from the large number of publications on the subject. Some have successfully put pressure on authorities to amend and to implement the laws. ${ }^{5,20,35}$ The subject has had a lot of media attention in the past 20 years and especially since the last publication of the Census of India in 2011. Recently, an Indian TV documentary on female feticide, produced and presented by a well-known Bollywood actor, has opened up a debate on the subject. ${ }^{62}$ An international film "It's a girl" about the missing girls in China and India has been shown in many US and
European cities and to members of the British Parliament. ${ }^{63}$ The idea of the film is to create public awareness of the problem. There is also an International Campaign aimed at applying international pressure on the Indian government to take action and enforce laws against female feticide, female infanticide, and dowry murders. ${ }^{64}$ All these steps are very positive, but it is too early to tell what effect these efforts are having and will have.

Following the recent high-profile rape case in Delhi (16 December 2012), the Indian government has acted with unprecedented speed under the pressure of public outrage, huge persistent demonstrations throughout India involving both women and men, and international media coverage. A report of a judicial committee appeared in January 2013, ${ }^{65}$ and the amendments to the law against rape (for future cases) were in place by early March. ${ }^{66}$ The perpetrators of the December rape were tried and sentenced in September 2013. ${ }^{67}$ This shows that public opinion matters. Furthermore, the media reports on this case have repeatedly linked high-crime rate against women to the skewed sex ratio as one of the possible causes and have thus raised public awareness of the effect of female feticide and infanticide.

\section{What might give results?}

In spite of the above mentioned efforts, the fact remains that the child sex ratio is continuing to decline at a disturbing rate.

There are those who think that changing the attitude of the people rather than stringent laws is the answer. ${ }^{4,84}$ However, changing cultural attitudes is a huge challenge in a vast country like India with $>1,200$ million people and several hundred languages. It will require a lot of time. But, we are running out of time. ${ }^{4,9}$

It is important to realize that although there has always been a cultural preference for a boy in some communities in some states of India, the problem was contained. In the past 40 years, this ancient cultural son preference has been fuelled and enhanced artificially by two modern factors: (i) the availability of increasingly easier methods of prenatal sex selection for the elimination of girls with the active participation of members of the medical profession who benefit financially and (ii) the everincreasing demands for dowry. Both these factors are economic and eliminating them lies in the realm of law. Enforcement of the existing laws is, therefore, essential., $3,6,35,53$

We think that programs mentioned above, which aim at changing the cultural attitudes and giving women more control over their lives, should be continued and expanded. In addition, compulsory and targeted education on the subject should be given to young boys and girls, starting from primary school and going on until the end of secondary school. This education should include basic information, such as respect for both sexes, evils of the dowry system, consequences of missing girls, and simple facts, e.g., that the sex of the baby is determined by the father. Such targeted education may have the desired effect in 10-15 years from now and may be the quickest way in which one can influence the rate of change in culture. 
The first and immediate step, however, is to stop further decline in sex ratio. Recent publicity of crime against women in India has already created greater awareness of the possible effects of skewed sex ratio. This momentum could be used to put pressure on the authorities at the national and international level to enforce the existing laws.

\section{DISCLOSURE}

The authors declare no conflicts of interest.

\section{REFERENCES}

1. Verma IC, Saxena R, Lall M, Bijarnia S, Sharma R. Genetic counseling and prenatal diagnosis in India-experience at Sir Ganga Ram Hospital. Indian J Pediatr 2003;70:293-297.

2. Subramanian SV, Corsi DJ. Can India achieve a balance of sexes at birth? Lancet 2011;377:1893-1894.

3. Allahbadia GN. The 50 million missing women. J Assist Reprod Genet 2002;19:411-416.

4. Oomman N, Ganatra BR. Sex selection: the systematic elimination of girls. Reprod Health Matters 2002;10:184-188.

5. George SM. Sex selection/determination in India: contemporary developments. Reprod Health Matters 2002;10:190-192.

6. George SM. Millions of missing girls: from fetal sexing to high technology sex selection in India. Prenat Diagn 2006;26:604-609.

7. Tandon SL, Sharma R. Female foeticide and infanticide in India: an analysis of crimes against girl children. Int J Crim Justice Sci 2006 http://www.sascv.org/ ijcjs/previousissues.html Accessed 8 August 2013.

8. Sharma BR, Gupta N, Relhan N. Misuse of prenatal diagnostic technology for sex-selected abortions and its consequences in India. Public Health 2007; 121:854-860

9. Aravamudan G. Disappearing Daughters: The Tragedy of Female Foeticide. Penguin Books: New Delhi, India, 2007.

10. Banerji R. Sex and Power Defining History, Shaping Societies. Penguin Books: New Delhi, India, 2008.

11. Census of India 2011. http://www.imaginmor.com/census-of-india-2011.html Accessed 8 August 2013.

12. Sen A. Missing women. BMJ 1992;304:587-588

13. Geneva Centre for the Democratic Control of Armed Forces (DCAF). Women in an Insecure World. (2005) 1. http://www.unicef.org/emerg/files/women insecure_world.pdf Accessed 8 August 2013.

14. Das Gupta M. Selective discrimination against female children in rural Punjab. Popul Dev Rev 1987;13:77-100.

15. George SM. Female infanticide in Tamil Nadu, India: from recognition back to denial? Reprod Health Matters 1997;10:124-132.

16. Khanna R, Kumar A, Vaghela JF, Sreenivas V, Puliyel JM. Community based retrospective study of sex in infant mortality in India. BMJ 2003:327:126

17. Ramanamma A, Bambawale U. The mania for sons: an analysis of social values in South Asia. Soc Sci Med Med Anthropol 1980;14:107-110.

18. Basu AM. Is discrimination in food really necessary for explaining sex differentials in mortality? Pop Stud J Demog 1989;43:193-210. http://www.tandfonline. com/doi/abs/10.1080/0032472031000144086\#.UgOc-m0sJ4M Accessed 8 August 2013.

19. Saravanan S. Female infanticide in India: a review of literature. Soc Change 2002;32:58-66. http://sch.sagepub.com/content/32/1-2/58 Accessed 8 August 2013.

20. Singh BP. Sociology of female foeticide and infanticide. Where does the law stand? Gender Forum. An internet journal for gender studies. 2012;38. http://genderforum.org/issues/passages-to-india/ Accessed 8 August 2013

21. Deshpande JD, Phalke DB, Phalke VD. Prenatal sex determination: issues and concerns. Pravara Med Rev 2009;1:4-6. http://www. pravara.com/pmr/pmr-11-2.pdf Accessed 8 August 2013.

22. Praveen S. Female infanticide. J Indian Acad Forensic Med 2011;33:366-369. http://imsear.hellis.org/bitstream/123456789/143424/1/jiafm2011v33i4p366. pdf Accessed 8 August 2013.

23. Lancet India Correspondent. Misuse of amniocentesis. Lancet 1983;321:812813.
24. Lancet India Correspondent. Protest against fetal sex selection. Lancet 1986;328:1090

25. George SM. Sex ratio in India. Lancet 2006;367:1725; author reply 1727 .

26. Puri $S$, Adams V, Ivey $S$, Nachtigall RD. "There is such a thing as too many daughters, but not too many sons": a qualitative study of son preference and fetal sex selection among Indian immigrants in the United States. Soc Sci Med 2011;72:1169-1176

27. Fugger EF, Black SH, Keyvanfar K, Schulman JD. Births of normal daughters after MicroSort sperm separation and intrauterine insemination, in-vitro fertilization, or intracytoplasmic sperm injection. Hum Reprod 1998;13:2367-2370.

28. Johnson LA. Sexing mammalian sperm for production of offspring: the state-ofthe-art. Anim Reprod Sci 2000;60-61:93-107.

29. Malpani A. Why shouldn't couples be free to choose the sex of their baby? Reprod Health Matters 2002;10:192-193.

30. Malpani A, Malpani A, Modi D. Preimplantation sex selection for family balancing in India. Hum Reprod 2002;17:11-12.

31. Benn P, Cuckle H, Pergament E. Non-invasive prenatal testing for aneuploidy: current status and future prospects. Ultrasound Obstet Gynecol 2013;42:1533.

32. Jha $P$, Kesler MA, Kumar $R$, et al. Trends in selective abortions of girls in India: analysis of nationally representative birth histories from 1990 to 2005 and census data from 1991 to 2011. Lancet 2011;377:1921-1928.

33. Jha P, Kumar R, Vasa P, Dhingra N, Thiruchelvam D, Moineddin R. Low female[corrected]-to-male [corrected] sex ratio of children born in India: national survey of 1.1 million households. Lancet 2006;367:211-218.

34. Bhat M. Sex ratio in India. Lancet 2006;367:1725-1726; author reply 1727.

35. Mudur G. Doctors in India prosecuted for sex determination, but few convicted. BMJ 2006;332:257

36. Lai-wan CC, Blyth E, Hoi-yan CC. Attitudes to and practices regarding sex selection in China. Prenat Diagn 2006;26:610-613.

37. Stone L, James C. Dowry, bride-burning and female power in India. Womens Stud Int Forum 1995;18:125-134.

38. Varghese J, Aruldas V, Jeemon P. Analysis of trends in sex ratio at birth of hospitalised deliveries in the state of Delhi 2005. http://www.unimondo.org/ layout/set/print/content/download/16604/109967/file/ANALYSIS\%200F\%20 TRENDS\%20IN\%20SEX\%20RATIO.pdf Accessed 8 August 2013.

39. Das Gupta M, Bhat M. Fertility decline and increased manifestation of sex bias in India. Pop Stud J Demog 1997;51:307-315. http://www.tandfonline.com/ doi/abs/10.1080/0032472031000150076\#.UgOdZ20sJ4M Accessed 8 August 2013

40. Hesketh T, Lu L, Xing ZW. The effect of china's one-child family policy after 25 years. N Eng/ J Med 2005;353:1171-1176.

41. Bloch F, Rao V. Terror as a bargaining instrument: a case study of dowry violence in rural India. Am Econ Rev 2002;92:1029-1043.

42. Kumar V. Poisoning deaths in married women. J Clin Forensic Med 2004;11:25.

43. Kumar V, Kanth S. Bride burning. Lancet 2004;364(suppl 1):s18-s19.

44. National Bureau of crime 2011. http://ncrb.nic.in/CD-CII2011/ compendium2011.pdf Accessed 8 August 2013.

45. Rao V. The rising price of husbands: a hedonic analysis of dowry increases in rural India. J Polit Econ 1993;101:666-677.

46. Anderson S. Why dowry payments declined with modernization in Europe but are rising in India. J Polit Econ 2003:111:269-310.

47. National Bureau of Crime 2010. http://ncrb.nic.in/CII2010/Compendium2010 pdf Accessed 8 August 2013

48. Times of India. Human trafficking is thriving business in Rajasthan. Times of India: Jaipur, India, 7 Feburary 2012. http://articles.timesofindia.indiatimes. com/2012-02-07/jaipur/31033379_1_girls-delhi-police-gangs Accessed 8 August 2013.

49. BBC News. India's a 'bride buying' country. BBC News, 5 April 2006. http:// news.bbc.co.uk/2/hi/south_asia/4862434.stm Accessed 8 August 2013.

50. UNICEF. UNICEF India Statistics, child protection 2012. http://www. unicef.org/ infobycountry/india_statistics.html Accessed 8 August 2013.

51. ICRW. Child marriage facts and figures. The International Centre for Research on women 2012. http://www.icrw.org/child-marriage-facts-and-figures Accessed 8 August 2013.

52. Hudson VM, Den Boer A. A surplus of men, a deficit of peace: security and sex ratios in Asia's largest states. Int Secur 2002;26:5-38.

53. Karat B, George S. Don't trash this law, the fault lies in non-implementation. The Hindu: India, 4 February 2012. http://www.thehindu.com/opinion/op-ed/ dont-trash-this-law-the-fault-lies-in-nonimplementation/article2858004.ece Accessed 8 August 2013. 
54. Kishwar M. Abortion of female fetuses: is legislation the answer? Reprod Health Matters 1993;2:113-115.

55. Sekher TV. UNFPA (United Nations Population Fund India) publication 39772 special financial incentive schemes for the girl child in India 2010. http://www. unfpa.org/gender/docs/sexselection/UNFPA_Publication-39772.pdf Accessed 8 August 2013

56. INSA. Science career for Indian women. Indian National Science Academy report 2004. http://www.ias.ac.in/womeninscience/INSA_1-17.pdf Accessed 8 August 2013.

57. Censusmp 2011. http://censusmp.gov.in/censusmp/All-PDF/5Gender Composition21.pdf Accessed 8 August 2013.

58. Dubuc S, Coleman D. An increase in the sex ratio of births to India-born mothers in England and Wales: evidence for sex selective abortion. Popul Dev Rev 2007;33:383-400.

59. Almond D, Edlund L. Son-biased sex ratios in the 2000 United States Census. Proc Natl Acad Sci USA 2008;105:5681-5682.

60. Egan JF, Campbell WA, Chapman A, Shamshirsaz AA, Gurram P, Benn PA Distortions of sex ratios at birth in the United States; evidence for prenatal gender selection. Prenat Diagn 2011;31:560-565.

61. Ray JG, Henry DA, Urquia ML. Sex ratios among Canadian liveborn infants of mothers from different countries. CMAJ 2012;184:E492-E496.

62. Satyamev Jayate. Indian TV documentary 2012. www.satyamevjayate.in/ Accessed 8 August 2013
63. It's a girl. Documentary film 2012. www.itsagirlmovie.com/ Accessed 8 August 2013.

64. International Campaign. The 50 million missing campaign: fighting female gendercide in India. 2008. http://50millionmissing.wordpress.com/ Accessed 8 August 2013.

65. Verma JS, Seth L, Suramanium G. Report of the Committee on Amendments to criminal law 2013. http://www. prsindia.org/uploads/media/Justice $\% 20$ verma\%20committee/js\%20verma\%20committe\%20report.pdf Accessed 14 September 2013.

66. $\mathrm{BBC}$ news India. Explaining India's new anti-rape laws. BBC News, 28 March 2013. http://www.bbc.co.uk/news/world-asia-india-21950197 Accessed 14 September 2013.

67. BBC news India. Delhi Gang rape: four sentenced to death. BBC News, 13 September 2013. http://www.bbc.co.uk/news/world-asia-india-24078339 Accessed 13 September 2013.

$(1) \otimes$ This work is licensed under a Creative Commons Attribution-NonCommercial-No Derivative Works 3.0 License. To view a copy of this license, visit http://creativecommons.org/licenses/by-nc-nd/3.0/ 